\title{
STUDI ANALISIS PUTUSAN PENGADILAN AGAMA JAKARTA SELATAN NO. 1751/P/1989 TENTANG PERKAWINAN MELALUI TELEPON
}

\author{
Muhajir \\ Dosen Fakultas Syariah IAIN Langsa \\ Jl. Meurandeh-Kota Langsa
}

\begin{abstract}
The legal basis of marriage law in Indonesia Constitution No. 1 of 1974 concerning Marriage and Compilation of Islamic law which is a reduction of Islamic rules regarding marriage, divorce, representation and inheritance originating from classical Islamic jurisprudence literature from various schools which are summarized and adapted to the needs of the people of Indonesia. The two legal bases regarding the marriage are expected to be a legal basis for the Indonesian people who will carry out the marriage. But in the practice of implementing marriage in the community, many new things appear that are ijtihad because there are no rules specifically set out to regulate such matters such as marriage through telephone.
\end{abstract}

Keywords: Marriage, Compilation of Islamic Law, Madhhab

\begin{abstract}
Abstrak. Dasar hukum perkawinan di Indonesia secara yuridis adalah Undang-Undang No. 1 Tahun 1974 Tentang Perkawinan dan Kompilasi hukum Islam yang merupakan reduksi dari aturan-aturan Islam mengenai perkawinan, perceraian, perwakafan dan pewarisan ini bersumber dari literatur-literatur fikih Islam klasik dari berbagai mazhab yang dirangkum dan disesuaikan dengan kebutuhan masyarakat Indonesia. Kedua dasar hukum mengenai perkawinan tersebut diharapkan dapat menjadi pijakan hukum bagi rakyat Indonesia yang akan melaksanakan perkawinan. Namun dalam praktek pelaksanaan perkawinan yang berlaku di masyarakat, banyak muncul hal-hal baru yang bersifat ijtihad dikarenakan tidak ada aturan yang tertuang secara khusus untuk mengatur hal-hal tersebut seperti nikah melalui telepon.

Kata Kunci: Perkawinan, Kompilasi Hukum Islam, Mazhab
\end{abstract}

\section{Pendahuluan}

Sebagai fukaha dalam mengemukakan hakekat perkawinan hanya menonjolkan aspek lahiriyah yang bersifat normatif. Seolah-olah akibat sahnya sebuah perkawinan hanya sebatas timbulnya kebolehan terhadap sesuatu yang sebelumnya sangat dilarang, yakni berhubungan badan antara laki-iaki dengan perempuan. Dengan demikian yang menjadi inti pokok pemikahan itu adalah akad (pernikahan) yaitu serah terima antara orang tua calon mempelai wanita dengan calon mempelai laki-laki.

Perkawinan umat Islam di Indonesia juga mengacu pada pedoman hukum Islam. Dengan perkataan lain hukum perkawinan yang berlaku di Indonesia sesuai dengan hukum islam sebagaimana pemahaman kalangan fukaha. Perkawinan juga bertujuan untuk memperluas dan mempererat hubungan kekeluargaan, serta membangun masa depan individu keiuarga dan masyarakat yang lebih baik. Oleh karena itu, jika telah ada kesepakatan antara orang pemuda dengan seorang pemudi untuk meiaksanakan akad nikah pada hakekatnya kedua belah pihak telah sepakat untuk merintis jalan menuju kebahagiaan lahir batin melalui pembinaan yang ditetapkan agama.

Barangkali, faktor-faktor yang ditetapkan terakhir inilah yang lebih mendekati tujuan hakekat dari perkawinan yang diatur oleh Islam. Oleh sebab itu, sah tidaknya perkawinan menurut Islam adalah tergantung pada akadnya. Karena sedemikian rupa pentingnya akad daiam perkawinan itu maka berdasarkan dalil-dalil yang ditemukan, para fuqoha' telah berijtihad menetapkan syarat-syarat dan rukun untuk sahnya sesuatu akad nikah. Sebagaimana hasil ilmu pengetahuan dan teknologi mengenai 
permasalahan baru dalam soal perkawinan yaitu tentang sahnya akad nikah yang ijâb qabûlnya dilaksanakan melalui telepon.

\section{Uraian Singkat Perkara}

Kurang lebih satu dekade yang lalu, muncul peristiwa menarik dalam hal pelaksanaan akad nikah yang dilakukan secara tidak lazim dengan menggunakan media teiepon. Peristiwa akad nikah lewat teiepon mengundang reaksi yang cukup luas dari masyarakat. Contoh yaitu pada tanggal $13 \mathrm{Mei}$ 1989 terjadi akad nikah jarak jauh Jakarta Bloomington Amerika Serikat lewat telepon, yang dilangsungkan di kediaman Prof. Dr. Baharuddin Harahap di Kebayoran Baru Jakarta. Calon suami Drs. Ario Sutarto yang sedang bertugas belajar di program Pascasarjana Indiana University Amerika Serikat, sedangkan calon istri adalah Dra. Nurdiani, putri guru besar IAIN Jakarta itu. Kedua calon suami istri itu sudah lama berkenalan sejak sama-sama belajar dari tingkat satu IKIP Jakarta, dan kehendak keduanya untuk nikah juga sudah mendapat restu dari orang tua kedua belah pihak.

Sehubungan dengan tidak bisa hadirnya calon mempelai laki-laki dengan alasan tiadanya biaya perjalanan pulang pergi Amerika Serikat-Jakarta dan studinya agar tidak terganggu, maka disarankan oleh pejabat pencatat nikah (KUA) agar dilusahakan adanya surat tawkil (delegation of authority) dari calom suami kepada seseorang yang bertindak mewakilinya dalam akad nikah (ijâb qabûl) nantinya di Jakarta.

Setelah waktu pelaksanaan akad nikah tinggal sehari belum juga datang Surat taukil itu, padahal surat undangan untuk walimatu al-urs sudah tersebar, maka Baharuddin sebagai ayah dan wali pengantin putri mempersiapkan segala sesuatu yang berkaitan dengan upacara akad nikah pada tanggal 13 Mei 1989, antara lain dengan melengkapi pesawat telepon di rumahnya dengan alat (mikrofon) dan dua alat perekam, ialah kaset, tape recorder dan video. Alat pengeras suara itu dimaksudkan agar semua orang yang hadir di rumah Baharuddin dan juga di tempat kediaman calon suami di Amerika Serikat itu bisa mengikuti upacara akad nikah dengan baik, artinya semua orang yang hadir di dua tempat yang terpisah jauh itu dapat mendengarkan dengan jelas pertanyaan dengan ijâb dari pihak wali mempelai putri dan pernyataan qobul dari pihak mempelai lakilaki, sedangkan alat perekam itu dimaksudkan oleh Baharuddin sebagai alat bukti otentik atas berlangsungnya akad nikah pada hari itu.

Setelah akad nikah dilangsungkan lewat telepon, tetapi karena surat tawkil dari calon suami beium juga datang pada saat akad nikah dilangsungkan, maka kepala KUA Kebayoran Baru Jakarta Selatan tidak bersedia mencatat nikahnya dan tidak mau memberikan surat nikah, karena menganggap perkawinannya belum memenuhi syarat sahnya nikah, yakni hadirya mempelai-łaki-laki-atau wakilnya.

Peristiwa nikah tersebut mengundang reaksi yang cukup luas dari masyarakat, terutama dari kalangan ulama dan cendekiawan muslim. Kebanyakan mereka menganggap tidak sah nikah lewat telepon itu, antara lain Munawir Syadzali, M.A Mentri Agama RI, K.H. Hasan Basri, ketua umum MUI pusat, dan Prof. Dr. Hasbullah Bakri, S.H. jadi, mereka dapat membenarkan tindakan kepala KUA tersebut yang tidak mau mencatat nikahnya dan tidak memberikan surat nikahnya. Dan inti alasan mereka ialah bahwa nikah itu termasuk ibadah mengandung nilai sacral, dan nikah lewat telepon itu bisa menimbulkan confused (keraguan) dalam hal ini terpenuhi tidaknya rukun-rukun nikah dan syarat-syarat secara sempurna menurut hukum Islam

Kemudian status pemikahan ini dimohonkan pengesahan melałui Pengadilan Agama Jakarta Selatan. Oleh Pengadilan Agama Jakarta Selatan hukumya dikukuhkan dengan dikeluarkannya Surat Putusan No. 1751/P/1989. Meski Pengadilan Agama Jakarta Selatan mengesahkan praktek semacam ini, namun putusan ini tetap dianggap riskan.

Peristiwa yang serupa dengan itu terulang kembali. Kali ini praktek akad nikah tertolong dengan dunia teknologi yang selangkah lebih maju dengan menggunakan fasilitas video teleconference. Teknoiogi video teleconference lebih mutakhir dari telepon, karena selain menyampaikan suara, teknologi ini dapat menampilkan gambar/citra secara realtime meialui jaringan internet. Hal ini seperti 
yang dipraktekkan oleh pasangan Syarif Aburahman Achmad ketika menikahi Dewi Tarumawati pada 4 Desember 2006 silam. Ketika pelaksanaan akad nikah, sang mempelai pria sedang berada di Pittsburgh, Amerika Serikat. Sedangkan pihak wali beserta mempeiai wanita berada di Bandung, Indonesia. Kedua belah pihak dapat melaksanakan akad nikah jarak jauh berkat layanan video teleconference dari indosat.

Hal ini tidak berbeda dengan apa yang dilakukan oleh pasangan Sirojuddin Arif dan Halimatus Sa'diyah. Dengan memanfatkan teknoiogi ini, mereka melangsungkan akad nikah mereka pada Maret 2007 silam. Hanya perbedaannya adalah, kedua mempelai sedang berada di aula kampus Oxford University, Inggris, sedangkan wali mempelai berada di Cirebon, Indonesia ketika akad nikah dilangsungkan.

Fenomena seperti ini menarik untuk dikaji dan dikomentari oleh para pakar hukum keluarga Islam di indonesia. Oleh sebab praktek akad nikah jarak jauh dengan menggunakan media teknologi ini belum pernah sekalipun dijumpai pada jaman sebelumnya. Praktek akad nikah pada jaman Nabi dan para Salafus shalih hanya menyiratkan diperbolehkannya metode tawkil, yakni pengganti pelaku akad apabila pihak pelaku akad (baik wali maupun mempelai pria) berhalangan untuk melakukannya.

\section{Bersatu dalam Majelis dalam Ijâb dan Qabûl}

Puncak dari pelaksanaan akad nikah adalah ijâbqabûl (yang merupakan rukun terakhir dari akad nikah). Sah atau tidaknya suatu akad nikah tergantung kepada sah atau tidaknya ijâb-qabûl yang dilakukan. Karenanya, tidak heran jika untuk melakukan ijâb-qabûl biasanya penghulu melakukan pengkondisian suasana dengan pembacaan istighfar, syahadat, dan shalawat. Tujuannya agaknya untuk menyiapkan hati, menghadirkan kalbu, dan meluruskan niat, agar ijâb-qabûl yang akan dilaksanakan dapat berlangsung dengan sempurna sesuai ketentuan syariat.

Abdurrahman Al-Jaziri menukil kesepakatan ulama mujtahid mensyaratkan bersatu majelis bagi ijâb qabûl. Dengan demikian apabila tidak bersatu antara majelis mengucapkan ijâb dengan majelis mengucapkan qabûlnya dianggap tidak sah. ${ }^{1}$ Pertanyaannya adalah apa yang dimaksud dengan bersatu "majelis" itu? Setelah meneliti pendapat ulama, terdapat dua penafsiran terhadap apa yang dimaksud dengan ittihad (bersatu) majelis sebagai berikut.

Pertama, yang dimaksud dengan ittihâd al-majelis ialah bahwa ijâb dan qabûl harus dilakukan dalam jarak waktu yang terdapat dalam satu upacara akad nikah, bukan dilakukan dalam dua ajarak waktu secara terpisah, dalam arti bahwa ijâb diucapkan dalam satu upacara, kemudian setelah upacara ijâb bubar, qabûl diucapkan pula pada acara berikutnya. Dalam hal yang disebut terakhir ini, meskipun dua acara berturut-turut secara terpisah bisa jadi dilakukan dalam satu tempat yang sama, namun karena kesinambungan antara ijâb dan qabûl itu terputus maka akad nikah tersebut tidak sah.

Dengan demikian, adanya persyaratan bersatu majelis, adalah menyangkut keharusan kesinambungan waktu antara ijâb dan qabûl, bukan menyangkut kesatuan tempat. Karena, seperti dikemukakan di atas meskipun tempatnya bersatu, tetapi apabila dilakukan dalam dua waktu, dalam dua acara yang terpisah, maka kesinambungan antara pelaksanaan ijâb dan pelaksanaan qabûl sudah tidak berwujud, dan oleh karena itu akad nikahnya tidak sah. Sayid Sabiq dalam menjelaskan arti bersatu majelis bagi ijâb dan qabûl, menekankan kepada pengertian tidak boleh terputusnya antara ijâb dan qabûl.

Satu contoh dikemukakan oleh al-Jaziri dalam memperjelas pengertian bersatu majelis dalam mazhab Hanafi adalah dalam masalah seorang lelaki berkirim surat mengakadkan nikah kepada pihak perempuan yang dikehendakinya. Setelah surat itu sampai, lalu isi surat itu dibacakan di depan wanita dan para saksi, dan dalam majelis yang sama setelah isi surat dibacakan, wali perempuan langsung mengucapkan penerimaannya (qabûlnya), Praktik akad nikah mikas seperti tersebut oleh kalangan Hanafiyah dianggap sah, dengan alasan bahwa pembacaan ijâb yang terdapat dalam surat calon

1 Abdurrahman Al-Jaziri, Al-Fiqh 'Ala al-Madzahib alArba'ah, (Beirut: Dar al-Fikr, t.th),hal.569. 
suami dan pengucapan qabûl dari pihak wali wanita, sama-sama didengar oleh dua orang saksi majelis yang sama, bukan dalam dua ucapan berturut-turut secara terpisah dari segi waktunya. Dalam contoh tersebut, ucapan akad nikah lebih dahulu diucapkan oleh calon suami, dan setelah itu baru pengucapan akad dari pihak wali wanita. ${ }^{2}$

Praktik tersebut boleh menurut mazhab Hanafi. Ucapan akad yang diucapkan lebih dahulu, disebut ijâb, baik diucapkan oleh wali, maupun oleh calon suami, dan ucapan akad yang disebut kemudian disebut qabûl, baik ia diucapkan oleh calon suami, maupun oleh calon istri, yang penting digaris bawahi dalam contoh tersebut bahwa yang didengar oleh para saksi adalah redaksi tertulis dalam surat calon suami yang dibacakan didepannya, dan si pembaca surat dalam hai ini bukan sebagai wakil dari calon suami, karena yang disebut terakhir ini dalam suratnya tidak mewakilkan kepada seorang pun. Apa yang dibacakan dari surat itu tidak lain dari redaksi langsung dalam bentuk tulisan calon suami.

Hal tersebut sejalan dengan penjelasan Sayid Sabiq bahwa apabila salah seorang dari dua pihak yang akan meiakukan akad nikah gaib (tidak bisa hadir), maka jalan keluarnya, disamping bisa dengan mengutus wakil, juga bisa dengan menulis surat kepada pihak lain untuk menyampaikan akad nikahnya. Bagi yang menerima surat jika menyetujui isi surat itu, hendaklah menghadirkan para saksi dan di depan mereka redaksi si rat itu dibacakan. Menurut Said Sabiq praktik seperti itu adalah sah, selama pei gucapan qabûlnya dilakukan langsung dalam satu majelis. Dalam praktik tersebut jelas bahwa dua orang saksi itu hanya mendengar redaksi surat yang dibacakan di depannya, yang bukan dalam bentuk tawkil. ${ }^{3}$

Dari keterangan di atas, dapat dipahami bahwa masalah esensi dari persyaratan bersatu majelis adalah menyangkut masalah keharusan kesinambungan antara ijâb dan qabûl. Adanya persyaratan tidak boleh ada batas yang berarti antara ijâb dan qabûl. Adanya persyaratan tidak boleh ada

2 Abdurrahman Al-Jaziri, Al-Fiqh 'Ala al-Madzahib alArba'ah, hal.570.

${ }^{3}$ Sayid Sabiq, Fiqh As-Sunnah, (Beirut: Dar al Fiqr,1983), cet.ke-4,h.327 batas yang berarti antara ijâb dan qabûl, dimaksudkan sebagai pendukung bagi kepastian bahwa ijâb dan qabûl itu benar-benar sebagai manifestasi dari perasaan rela dari kedua belah pihak untuk mengadakan akad nikah. Qabûl yang langsung diucapkan setelah ijâb dan qabûl, bisa jadi menunjukkan bahwa calon suami tidak lagi sepenuhnya rela untuk mengucapkan qabûl, dan wali nikah dalam jarak waktu itu bisa jadi sudah tidak lagi pada pendiriannya semula, atau telah mundur dari kepastiannya.

Maka untuk lebih memastikan bahwa masingmasing masih dalam kerelaannya, kesinambungan antara ijâb dan qabûl dipandang sebagai satu kesatuan yang tidak bisa dipisahkan. Untuk menjaga kesatuan itulah diisyarakan pula bersatu majelis melakukan akad. Persyaratan bersatu majelis, apabila dimaksudkan hanya untuk kesinambungan waktu, maka bersatu tempat bukan satu-satunya untuk mewujudkan kesinambungan waktu. Umpamanya seorang wali mengucapkan ijâb di saru ruangan, sedangkan calon suami mengucapkan qabûl di ruangan yang lain pada upacara dalam waktu yang bersamaan, dengan memakai alat pengeras suara, kesinambungan antara ijâb dan qabûl jelas dapat dipastikan.

Konsekuensi dari pandangan ini, dua orang saksi tidak mesti dapat melihat pihak-pihak yang melakukan akad nikah. Ibnu Qudamah salah seorang ahli fiqh dari kalangan Hanbali menegaskan keabsahan kesaksian dua orang buta untuk akad nikah, dengan alasan bahwa yang akan disaksikan adalah suara. Menurutnya kesaksian orang buta dapat diterima, selain ia dapat memastikan secara yakin bahwa suara itu benar-benar diucapkan oleh dua orung yang melakukan akad nikah. ${ }^{4}$ Pendapat Ibnu Qudamah tersebut dikuti oleh Sayid Sabiq dalam kitabnya Fiqh as-Sunnah.

Apabila dikuti keterangan di atas, dan digabungkan antara keabsahan mengucapkan $i j a ̂ b$ dan qabûl melalui surat, dengan keabsahan kesaksian dua orang buta, maka masalah bahwa dua orang saksi harus mampu melihat kedua orang yang sedang

${ }^{4}$ Ibnu Qudamuh, Al-Mugni, (Mulbu'ah al-Quhiruh,1970), hal.768.

Studi Analisis Putusan Pengadilan Agama Islam|12 
mengucapkan ijâb dan qabûl, sudah tidak menjadi penting, dan dengan demikian, masalah keharusan hadir kedua belah pihak dalam satu ruangan dengan alasan dapat dilihat, tidak lagi dianggap menjadi syarat bagi keabsahan akad nikah.

Kedua, ialah pendapat yang menegaskan bahwa bersatu majelis disyaratkan, bukan saja untuk menjamin kesinambungan antara ijâb dan qabûl, tetapi sangat erat hubungannya dengan tugas dua orang saksi yang menurut pendapat ini, harus dapat melihat dengan mata kepalanya bahwa ijâb dan qabûl itu betul-betul diucapkan oleh kedua orang yang melakukan akad. Seperti diketahui bahwa di antara syarat sah suatu akad nikah, dihadiri oleh dua orang saksi. Tugas dua orang saksi itu, seperti disepakati para ulama, terutama untuk memastikan secara yakin akan keabsahan ijâb dan qabûl, baik dari segi redaksinya, maupun dari segi kepastian bahwa ijâb dan qabûl itu adalah diucapkan oleh kedua belah pihak.

Dimaklumi bahwa keabsahan suatu redaksi dapat dipastikan dengan cara mendengarkannya. Akan tetapi, bahwa redaksi itu benar-benar asli diucapkan oleh kedua orang yang sedang melakukan akad, kepastiannya hanya dapat dijamin dengan jalan melihat para pihak yang mengucapkan itu dengan mata kepala. Pendapat ini, kesaksian orang buta tidak dapat diterima untuk akad nikah. Ibnu Hajar alHaisami, seorang pakar hukum fiqh dari kalangan Syafi'iyah (wafat tahun $973 \mathrm{H}$ ) menolak kesaksian orang buta, alasannya karena kesaksian nikah harus didasarkan atas penglihatan dan pendengaran. ${ }^{5}$

Kesaksian orang buta menurutnya sama dengan kesaksian seseorang yang berada dalam gelap gulita. Kedua kesaksian itu tidak sah, karena sama-sama tidak dapat melihat yang sedang melakukan akad, dan karena itu ia tidak dapat memastikan bahwa ijâb dan qabûl benar-benar diucapkan oleh kedua belah pihak yang berakad. Syekh Abdul Hamid asy-Syarwani dalam komentarnya terhadap ketetapan Ibnu Hajar tersebut mengatakan "Kesaksian orang dalam gelap tidak sah, karena tidak dapat mengetahui kedua orang yang sedang melakukan akad. Sedangkan berpegang

\footnotetext{
${ }^{5}$ Al-Haitsani, Tufhatul Muhtaj, (Beirut: Dar al-Fiqr, t.th), hal. 890.
}

kepada suara saja tidaklah memadai. Seandainya kedua orang saksi mendengar ijâb dan qabûl, tetapi tidak melihat kedua orang yang mengucapkannya, meskipun dua orang saksi mengetahui betul bahwa ijâb dan qabûl adalah suara dari kedua belah pihak, namun akad nikahnya tetap dianggap tidak sah dengan alasan tidak dilihat dengan mata kepala (almu'ayanah). ${ }^{6}$

Dalam nukilan di atas dipahami, bahwa untuk keabsahan kesaksian akad nikah, ada satu target keyakinan yang harus diwujudkan oleh para saksi dalam kesaksiannya. Meskipun suatu redaksi dapat diketahui siapa pembicaranya dengan bobotnya tidak akan sampai ke tingkat keyakinan apabila dilihat pengungkapannya dengan mata kepala. Sedangkan dalam akad nikah, tingkat keyakinan yang disebut terakhir inilah yang diperlukan. Pandangan tersebut, sangat erat hubungannya dengan sikap para ulama terutama kalangan Syafi'iyah yang selalu bersikap hati-hati dalam menetapkan suatu hukum, lebih-lebih lagi dalam masalah akad nikah. yang berfungsi sebagai penghalalan dari sesuatu yang tadinya diharamkan.

Oleh karena kesaksian harus didasarkan atas pendengaran dan penglihatan, menurut pandangan ini ijâb dan qabûl melalui surat tanpa mewakilkan, tidak sah. Oleh karena itu pula mengapa Imam Namawi menjelaskan, apabila salah seorang dari dua pihak yang melakukan akad nikah mengucapkan ijâbnya dengan jalan berteriak dari tempat yang tidak dapat dilihat, dan teriakan itu didengar oleh pihak lain, dan pihak yang terakhir ini langsung mengucapkan qabûlnya, akad nikah seperti itu tidak sah. ${ }^{7}$ Dalam pemahaman di atas secara tegas dapat diketahui bahwa, adanya persyaratan bersatu majelis, bukan hanya untuk menjaga kesinambungan waktu, tetapi juga mengandung persyaratan lain, yaitu almu'ayanah (kedua belah pihak sama-sama hadir dalam satu tempat), karena dengan itu persyaratan dapat melihat secara nyata pengucapan ijâb dan qabûl dapat diwujudkan.

\footnotetext{
${ }^{6}$ Al-Haitsani, Tufhatul Muhtaj, hal. 890.

${ }^{7}$ An-Nawawi, Al-Majmu' Syarh Al-Muhazzab, (Beirut: Dar Al-Fiqr,Lth),hal.671.
}

Studi Analisis Putusan Pengadilan Agama Islam|13 
Di samping hal-hal tersebut di atas, satu hal yang perlu digaris bawahi dalam pandangan mazhab Syafi'i ialah bahwa masalah akad mengandung arti ta'abbud yang harus diterima apa adanya. Oleh sebab itu, cara pelaksanaannya adalah masalah tauqifiyah, dalam arti harus terikat dengan pola yang telah diwariskan oleh Rasululah untuk umatnya. Itulah sebabnya mengapa ijâb dan qabûl itu lafalnya harus seperti terdapat dalam nash, seperti lafal nikah atau tazwij, bukan lafal yang lain dengan jalan Qiyas.

Dari keterangan di atas dapat diketahui pokokpokok pedoman Syafi'iyah dalam hai ini yaitu:

a. Kesaksian harus didasarkan atas pengihatan dan pendengaran. Oleh sebab itu kesaksian orang buta tidak dapat diterima. Untuk memenuhi persyaratan itu diisyaratkan bersatu majelis, daiam arti bersatu tempat secara fisik, karena dengan itu persyaratan al-mu'ayanah dengan arti dapat dilihat secara fisik, dapat dipenuhi. Pandangan tersebuut erat hubungannya dengan sikap hati-hati (ihtiyat) dalam masalah akad nikah.

b. Akad nikah mengandung arti ta'abbud. Oleh karena itu, pelaksanaannya harus terkait dengan apa yang telah dicontohkan oleh Rasulullah. Oleh karena akad nikah mengandung arti ta'abbud, pengembangan lewat analogi atau qiyâs tidak dapat diterima dalam pelaksanaannya. ${ }^{8}$

\section{Analisa Putusan PA No. 1751/P/1989 Tentang Perkawinan Melalui Telepon}

Prosesi ijâb-qabûl masih kontroversial, hampir semua imam fikih berpendapat ijâb -qabûl harus satu majelis. Namun ulama kontemporer, dengan menimbang persoalan ekonomi, baru-baru ini memperbolehkan perkawinan jarak jauh. Tentang perkawinan jarak jauh, menyangkut persoalan akad atau kontrak. Kontrak itu harus jelas, siapa yang melakukan akad, saksi dan walinya siapa. Apalagi perkawinan merupakan kontrak jangka panjang. Ada yang berpendapat bahwa momen perkawinan adalah penting, sehingga kedua mempelai harus hadir. Bukan persoalan sah dan tidak sah. Tapi secara

8 Satria Effendi M. Zein, Problematika Hukum Keluarga Islam Kontemporer: Analisis Yurisprudensi dengan Pendekatan Ushuliyah, (Jakarta: Kencana Prenada Media, 2004), hal. 8. moral, orang menikah itu harus hadir secara fisik. Karena ada kedekatan psikologis antara calon pengantin. Dan ada juga yang berpendapat, bahwa ijâb-qabûl sama dengan akad sehingga, kalau terpenuhi prinsip-prinsip kepastian, perkawinan bisa dilakukan jarak jauh. Sebagaimana hasil ilmu pengetahuan dan teknologi, muncul permasalahan baru dalam soal perkawinan yaitu tentang sahnya akad nikah yang ijâb-qabûlnya dilaksanakan melalui telepon. Ada contoh kasus yaitu ada seorang ayah yang ingin menikahkan anaknya, tetapi perjalanan seorang ayah tersebut masih tertunda di Jakarta sedangkan akad nikah yang dilaksanakan di Yogyakarta akan segera dilaksanakan karena rukun nikah sudah terpenuhi kecuali wali perempuan. Ayah dari mempelai perempuan tetap bersikeras ingin menikahkan anaknya sendiri tanpa diwakilkan. Jalan keluar yang diambil yaitu akad nikah dilaksanakan dengan menggunakan video call atau 3G. Dari kasus tersebut, timbul suatu keraguan apakah pernikahan tersebut sah atau tidak sehingga perlu diiakukan akad nikah ulang.

Sebagai perbandingan, di Mesir, berdasarkan buku laporan pelatihan hakim Indonesia gelombang II di Kairo, 2003, pengertian satu majelis tidak harus duduk dalam satu tempat. Oleh karenanya, ijâb-qabûl melalui telepon dipandang sah bila dapat dipastikan suara yang didengar adalah suara orang yang melakukan ijâb qabûl. Begitupun apabila ijâb-qabûl dilakukan lewat surat elektronik dibacakan oleh kuasanya yang sah di depan dua orang saksi nikah dan banyak orang. Adalah Abdurrahman Wahid alias Gus Dur yang pernah meiakukan perkawinan jarak jauh. la saat itu menempuh studi di Mesir dan saat ijâb-qab̂̂l mewakikan dirinya kepada orang lain lewat surat kuasa. Saat itu, Gus Dur sebagai mempelai pria diwakili kakeknya dari garis ibu, $\mathrm{KH}$ Bisri Syansuri. Dan ini membuktikan bahwa di Indonesia putusan pengadilan mengesahkan perkawinan lewat telepon. Rifyal yang menyabet gelar master dari Department of Social Sciences, Kairo, Mesir menganalogikan ijâb dan qabûl perkawinan dengan perdagangan yang menurut Islam juga harus dilakukan dalam satu majelis.

Menentukan sah atau tidaknya suatu nikah, tergantung pada dipenuhi atau tidaknya rukun-rukun 
nikah dan syarat-syaratnya. Secara formal, nikah lewat telepon dapat memenuhi rukun-rukunnya, yakni adanya calon suami dan istri, dua saksi, wali pengantin putri, dan ijâb qabûl. Namun, jika dilihat dari segi syarat-syarat dari tiap-tiap rukunnya, tampaknya ada kelemahan atau kekurangan untuk dipenuhi. Misalnya, identitas calon suami istri perlu dicek ada atau tidaknya hambatan untuk kawin (baik karena adanya larangan agama atau peraturan perundang-undangan) atau ada tidaknya persetujuan dari kedua belah pihak.

Pengecekan masalah ini lewat telepon sebelum akad nikah adalah cukup sukar. Demikian pula pengecekan tentang identitas wali yang tidak bisa hadir tanpa taukil, kemudian ia melangsungkan ijâbqabûl langsung dengan telepon. Juga para saksi yang sahnya mendengar pernyataan ijâb-qabûl dari wali dan pengantin putra lewaat telepon dengan bantuan mikropon, tetapi mereka tidak melihat apa yang disaksikan juga kurang meyakinkan. Demikian pula ijâb-qabûl yang terjadi di tempat yang berbeda lokasinya, apalagi yang sangat berjauhan seperti antara Jakarta dan Bloomington Amerika Serikat yang berbeda waktunyasekitar 12 jam.

Oleh karena itu, nikah lewat telepon itu tidak sah dan tidak dibolehkan menurut hukum islam, karena selain terdapat kelemahan atau kekurangan dan keraguan dalam memenuhi rukun-rukun nikah dan syarat-syaratnya, ada beberapa hal yang perlu diuraikan berikut ini:

c. Nikah itu termasuk ibadah, Oleh karena itu, pelaksanaan nikah harus sesuai dengan tuntunan Alqur'an dan Sunnah Nabi yang shahih, berdasarkan kaidah hukum: "Pada dasarnya, ibadah itu haram". Artinya, dalam masalah ibadah, manusia tidak boleh membuat-buat (merekayasa aturan sendiri).

d. Nikah merupakan peristiwa yang sangat penting dalam kehidupan manusia, dan itu bukanlah sembarangan akad, tetapi merupakan akad yang mengandung sesuatu yang sakral dan syiar lslam serta tanggungjawab yang berat bagi suami istri, sebagaimana firman Allah: "Dan mereka (isteriisterimu) telah mengambil dari kamu perjanjian yang kuat." (Q.S. An-Nisa': 21) e. Nikah lewat telepon mengandung risiko tinggi berupa kemungkinan adanya penyalahgunaan atau penipuan (gharar atau Khida'), dan dapat pula menimbulkan keraguan (confused atau syak), apakah telah dipenuhi atau tidak rukun-rukun dan syarat-syarat nikahnya dengan baik. Dan yang demikian itu tidak sesuai dengan kaidah fikih: "Tidak boleh membuat mudarat kepada diri sendiri dan kepada orang lain." Dan hadis Nabi: "Tinggalkanlah sesuatu yang meragukan engkau, (berpeganglah) dengan sesuatu yang tidak meragukan engkau."

Ada ulama yang berpendapat bahwa status nikah lewat teiepon itu syubhat. artinya belum safe, sehingga perlu tajdid nikah (nikah ulang) sebelum dua manusia yang berlainan jenis kelaminnya itu melakukan hubungan seksual sebagai suami istri yang sah. Adapula ulama yang berpendapat, bahwa nikah lewat telepon tidak diperbolehkan, kecuali dalam keadaan darurat. Tetapi kebanyakan ulama dan cendekiawan Muslim menganggap nikah lewat telepon itu tidak sah secara mutlak.

Proses pernikahan dalam Islam mempunyai aturan-aturan yang ketat. Sebuah akad pernikahan yang sah harus terpenuhi rukun dan syarat-syaratnya. Rukunnya adalah ijâb dan qabûl, sedang syaratnya adalah ijin dari wali perempuan dan kehadiran dua orang saksi. Ini semuanya harus dilakukan dengan jelas dan transparan, sehingga tidak ada unsur penipuan dan pengelabuhan. Oleh karena itu calon suami atau wakilnya harus hadir di tempat, begitu juga wali perempuan atau wakilnya harus hadir di tempat, dan kedua saksipun harus hadir di tempat untuk menyaksikan akad pernikahan.

Ketika seseorang menikah lewat telepon, maka banyak hal yang tidak bisa terpenuhi dalam akad nikah lewat telpon tadi, diantaranya: tidak adanya dua saksi, tidak adanya wali perempuan, dan tidak ketemunya calon pengantin ataupun wakilnya. Ini yang menyebabkan akad pernikahan tersebut menjadi tidak sah.

Seandainya dia menghadirkan dua saksi dan wali perempuan dalam akad ini, tetap saja akad pernikahan tidak sah karena kedua saksi tersebut tidak menyaksikan apa-apa kecuali orang yang 
sedang menelpon, begitu juga wali perempuan tidak berfungsi sebagaimana mestinya. Suara yang ada ditelpon itu belum tentu suara calon suami atau istri. Ringkasnya bahwa akad pernikahan melalui telpon berpotensi untuk salah, atau rentan terjadinya penipuan dan manipuiasi.

Disarankan siapa saja yang ingin menikah jarak jauh, untuk mewakilkan kepada orang yang dipercaya. Seandainya dia sebagai perempuan yang bekerja di luar negri, maka cukup walinya sebagai wakil darinya untuk menikahkan dengan lelaki yang diinginkannya, dan harus ada dua saksi yang hadir. Bagi seorang laki-laki yang ingin menikah dengan perempuan jarak jauh, maka hendaknya di mewakikan dirinya kepada orang yang dipercaya, seperti adik, kakak, atau saudaranya dengan dihadiri wali perempuan dan kedua saksi. Seandainya ada laki-laki dan perempuan yang ingin menikah di luar negeri dan jauh dari wali maka wali tersebut bisa mewakilkan kepada orang yang dipercayai. Wakil dari wali tersebut beserta kedua saksi harus hadir di dalam akad penikahan. Semua proses pemberian kuasa untuk mewakili hendaknya disertai dengan bukti-bukti dari instasi resmi terkait, supaya tidak disalahgunakan.

Masalah jarak yang memisahkan antara para pelaksana akad nikah dalam pandangan syariah sangat mudah solusinya. Baik yang terpisah adalah pasangannya atau pun walinya, atau bahkan ketiga pihak yaitu calon suami, calon isteri dan wali semua terpisah jarak. Toh tetap masih dimungkinkan adanya akad nikah. Tetapi yang solusinya bukan nikah jarak jauh, melainkan solusinya adalah taukil atau perwakilan. Seorang ayah kandung dari anak gadis yang seharusnya menjadi wali dalam akad nikah dan mengucapkan ijâb, dibenarkan dan dibolehkan untuk menunjuk seseorang yang secara syarat memenuhi syarat seorang wali. Dan penunjukannya boleh dilakukan secara jarak jauh, baik lewat surat tertulis atau pembicaraan telepon SLI, bahkan boleh lewat SMS, chatting, e-mail, atau Video Conference $3.5 \mathrm{G}$.

Cukup ditetapkan siapa yang akan menjadi wakil dari wali, yang penting tinggalnya satu kota dengan calon suami. Lalu dilakukanlah akad nikah secara langsung di satu majelis yang dihadiri oleh minimal 2 orang saksi laki-laki. Si wakil wali mengucapkan ijâb yang bunyinya kira-kira: "Saya sebagai wakil dari fulan (nama ayah si gadis) menikahkan kamu (nama calon suami) dengan fulanah binti fulan (nama gadis dan nama ayahnya) dengan mahar sekian sekian." Lalu calon suami menjawab (qabûl), kira-kira bunyinya: "Saya terima nikahnya fulanah binti fulanah dengan mahar tersebut tunai." Dan akad itu sudah sah.

Dan lebih menarik lagi, termyata perwakilan itu bukan saja boleh dilakukan oleh wali kepada wakilnya, tetapi calon suami pun boleh pula mewakilkan dirinya kepada orang lain. Sehingga namanya menjadi wakil calon suami melakukan proses qabûl. Misalnya seorang calon suami tidak mungkin bisa datang ke negara di mana ayah si gadis mau mewakilkan dirinya kepada orang iain. Berarti calon suami yang mengalah dan mewakilkan dirinya kepada seseorang yang tinggal di satu kota dengan ayah di gadis. Proses pewakilannya sama saja, boleh jarak jauh dan menggunakan berbagai teknologi informasi modern. Asalkan jangan pakai telepati saja, tidak sah karena tidak ada bukti otentik. Lalu si wakil calon suami melakukan akad nikah dengan ayah si gadis dan urusannya selesai.

Bahkan yang lebih fantastis lagi, ternyata kedua belah pihak pun masih dibenarkan untuk mengajukan wakil masing-masing. Sehingga yang melakukan akad nikah justru masing-masing wakilnya saja. Maka pernikahan jarak jauh bukanlah akad nikah dilakukan lewat telepon SLI atau yang lebih murah pakai VoIP, namun yang yang diiakukan secara jarak jauh adalah proses mewakilkannya. Sedangkan akad nikahnya harus dilakukan dalam satu majelis, face to face, meski hanya oleh wakil dari masing-masing. Untuk itu, harus ada saksi yang memenuhi syarat. adalah dua orang yang beragama Islam. Syaratnya mudah dan sederhana, tidak harus keluarga, famili atau kerabat. Bahkan tidak kenai pun tidak apa-apa. Yang penting saksi adalah dua orang yang beragama Islam, laki-laki, berakal, sudah baligh, adil dan merdeka (bukan budak). Dan syarat saksi ini kira-kira sama dengan syarat orang yang berhak untuk menjadi wakil dari wali.

Dalam syariat Islam, akad nikah tidak terjadi antara seorang calon suami dengan calon isteri. Melainkan antara ayah kandung seorang wanita 
dengan laki-laki yang akan menjadi suaminya. Maka tidak ada akad nikah kalau tidak melibatkan keduanya bersama. ${ }^{9}$ Adapun orang lain yang bukan ayahnya, lalu tiba-tiba mendadak mengangkat diri menjadi wali, maka dia telah bertindak sebagai wali gadungan. ${ }^{10}$ Akad nikah yang dilakukannya $100 \%$ tidak sah. Karena pada hakikatnya dia bukan wali sedangkan wanita itu masih punya wali yang sah.

Tidak ada masalah untuk melakukan nikah jarak jauh, di mana pengantin laki-laki dan pengantin perempuan tidak saling bertemu. Sama sekali tidak ada masalah karena akad nikah atau ijâb-qabûl dalam syariah Islam memang tidak terjadi antara pengantin laki-laki dan pengantin perempuan. Ijâb-qabûl terjadi antara pengantin laki-laki dengan ayah kandung atau wali dari pengantin perempuan. Maka cukuplah si pengantin laki-laki dan calon mertuanya itu saja yang mengucapkan ijâb qabûl. Asalkan ijâb-qabûl itu disaksikan oleh dua orang laki-laki muslim yang sudah aqil baligh, akad itu sudah sah.

\footnotetext{
${ }^{9}$ Sama dengan jual beli, kita diharamkan membeli barang dari orang yang bukan pemilik sah suatu barang. Misalnya dari penadah atau dari pencuri. Kita hanya boleh membeli barang dari pemiliknya. Paling tidak, atas izin dari pemilik barang. Misalnya kita beli sebidang tanah, jangan mau kalau orang yang mengakui sebagai pemilik tanah itu tidak bisa menunjukkan bukti-bukti kepemilikannya, misalnya SHM atau girik. Sebab kalau kita asal beli begitu saja, jangan-jangan tanah itu sudah ada yang punya. Kita akan terlibat sengketa tanah tak berkesudahan nantinya. Begitu juga ketika menikahkan anak, kita harus 'membeli' langsung dari 'pemiliknya', yaitu ayah kandung. Bukan maksud kami menyamakan seseorang wanita dengan barang, tetapi ini sekedar ilustrasi yang memudahkan. Kita ibaratkan seorang wanita adalah barang yang dimiliki oleh ayah kandungnya.maka lalu kita mau 'menikahinya', kita harus menyelesaikan akad dan transaksi dengan sang pemilik. Bukan dengan orang lain yang bukan pemilik.

${ }^{10}$ 'Wali Gadungan' adalah pencuri yang akan disiksa di neraka nanti, karena telah menyerobot hak milik orang lain. Bahkan bukan sekedar mencuri, dia akan disiksa pedih karena telah menghalalkan perzinahan. Dia telah menipu orang awam dengan fatwa sesatnya. Syarat multak dari sebuah pernikahan adalah akad antara ayah kandung pengantin wanita dengan seorang calon suami. Dalam implementasinya, seorang ayah kandung boleh saja meminta orang lain untuk bertindak mewakili dirinya, namun harus dengan penyerahan wewenag secara sah dan resmi. Tidak boleh dirampas begitu saja Sehingga pernikahan jarak jah tetap bisa dilakukan. Maksudnya, meski ayah kandung tidak ikut dalam akad nikah, dia oleh mewakilkan otoritasnya kepada orang lain yang memenuhi syarat sebagai wali untuk bertindak atas nama dirinya menikahkan putrinya. Akan tetapi kalau yang dimaksud dengan nikah jarak jauh adalah merampas hak seorang ayah kandung sebagai wali yang sah, maka hukumnya haram.
}

Bagi seorang wanita, tidak ada nikah tanpa wali. Dan wali adalah ayah kandungnya yang sah. Hanya di tangan ayah kandung sajalah seorang wanita boleh dinikahkan. Seandainya si ayah kandung tidak mampu menghadiri akad nikah anak gadisnya, maka dia boleh mewakilkan dirinya kepada orang lain yang dipercayainya. Namun hak untuk menjadi wali tidak boleh "dirampas" begitu saja dari tangan ayah kandung. Bila sampai perampasan itu terjadi, lalu wali gadungan itu menikahkan anak, gadis itu, maka akad nikah itu tidak sah. Kalau mereka melakukan hubungan suami isteri, hukumnya zina.

Yang lebih menarik, justru kehadiran petugas pencatat nikah yang biasanya memimpin ijâb qabûl, sama sekali tidak masuk dalam urusan sah atau tidaknya pernikahan. Meski tugas itu didapat dari pemerintah secara resmi, namun tanpa kehadirannya akad nikah bisa tetap berlangsung. Sementara anggapan sebagian masyarakat kita, petugas KUA ini seolah menjadi tokoh inti dari sebuah ijâb qabûl. Padahal tugas hanya sekedar mencatat secara administratiíf saja. Hadir atau tidak hadir, tidak ada urusan dengan sahnya sebuah akad nikah. Namun demikian, demi tertibnya administrasi negara, sebaiknya petugas ini dihadirkan juga, akan akad nikah itu secara resmi juga tercatat dengan baik di pemerintahan.

Memang benar apa yang anda katakan, sebuah pernikahan itu harus dilakukan oleh wali berdua melafadzkan ijâb dan qabûl yang disaksikan oleh minimal 2 orang laki-laki dari pihak perempuan dan pihak mempelai laki-laki. Mereka musim. Tanpa adanya keempat orang itu, nikahnya menjadi tidak sah. Karena ketentuan dan persyaratan scbuah pernikahan. Namun yang perlu diperjelas di sini, bahwa seorang wali diperkenankan untuk meminta orang lain untuk mewakili tugas dan wewenang. Orang lain yang ditunjuk ini, tentu saja harus benarbenar ditunjuk dalam arti kata yang sesungguhnya.

Dalam masyarakat, seringkali kita lihat orang tua mempelai wanita meski hadir dalam acara akad nikah itu, meminta kepada petugas pencatat nikah (KUA) untuk menjadi wakilnya. Sehingga yang mengucapkan $i j a \hat{a} b$ bukan orang tua mempelai wanita, melainkan petugas KUA. Petugas itu tidak boleh mengambil alih wewenang sebagai wali mempelai 
wanita, kecuali berdasarkan permintaan dari si wali tersebut. Demikian juga, mempelai laki-laki pun diperkenankan untuk meminta orang lain menjadi wakil dirinya, dalam akad nikah. Baik dirinya hadir dalam acara akad itu atau pun tidak. Namun yang kedua ini memang kurang lazim terjadi. Tapi secara hukum, bila memang hal itu yang dingininya, hukum tetap sah. Seluruh ulama salaf dan khalaf sepakat membolehkan masalah mewakikan wali nikah ini secara bulat. Baik Mazhab Abu Hanifah, Malik, AsSyafi'i dan Ahmad bin Hambal. Bahkan mazhab Abu Hanifah lebih jauh lagi dalam masalah ini, yaitu seorang wanita boleh menjadi wakil dari ayah kandungnya dalam Jumhur ulama mengatakan bahwa kebolehan mewakilkan wewenang kepada orang lain (tawkil) dalam menikahkan pasangan pengantin ini berlaku juga dalam hampir semua hal yang terkait dengan masalah muamalah. Seperti jual beli, sewa menyewa, gadai, salaf, istishna' dan lainnya. Sedangkan yang terkait dengan ibadah mahdhah dan bersifat langsung kepada Allah swt, tidak berlaku kecuali bila ada dalil. Shalat dan puasa tidak boleh diwakilkan kepada orang lain, namun ibadah haji termasuk rincian manasiknya seperti melontar jamarat dan lainnya, dimungkinkan untuk diwakilan. Lantaran ada dalil yang tegas atas hal itu. Termasuk yang boleh diwakilkan adalah menyembelih qurban yang dipersembahkan kepada Allah swt., di hari Raya Qurban.

Pada dasarnya menurut para ulama, tidak disyaratkan ada persaksian dalam proses pemberian wewenang unnuk menjadi wakil wali nikah. Namun mereka menganjurkan untuk dihadirkan saksi-saksi, untuk berjaga-jaga agar jangan sampai orang yang sudah menyerahkan wewenang kepada wakilnya, tiba-tiba mengingkarinya. Islam Memberi Kemudahan Namun Sesuai Prosedur.

Kemungkinan menunjuk wakil dalam akad nikah ini untuk menjawab masalahnikah jarak jauh, di mana wali mempelai wanita dan mempelai laki-laki sulit untuk bisa duduk dalam satu majelis.

Daripada mereka melakukan ijâb-qabûl lewat telepon, akan lebih utama bila secara sah mereka meminta orang lain mewakili mereka. Sebab ijâbqabûl jarak jauh ini masih meninggalkan banyak perdebatan. Lantaran ada keharusan disaksikan oleh dua orang saksi muslim, laki-iaki, yang sudah aqil dan baligh.

Sesuatu yang sulit dikerjakan bila dilakukan dengan jarak jauh dan bukan dalam satu majelis. Maka yang bisa kita simpulkan adalah bahwa setiap personal yang terkait dalam sebuah akad nikah boleh mewakilkan wewenangnya kepada orang lain. dalam hal ini adalah calon suami dan mertuanya. Keduanya berhak meminta orang lain untuk mewakili dirinya dalam sebuah akad. Sedangkan saksi nikah yang dua orang itu, memang tidak tergantikan, tetapi saksi boleh siapa saja, asalkan muslim, laki, aqil, baligh, merdeka dan adil.

Akad nikah atau ijâb-qabûl yang dilakukan oleh masing-masing wakil dari kedua belah pihak adalah sebuah bentuk keluwesan sekaligus keluasan syariah Islam. Namun kalau tiba-tiba ada orang mengangkat diri menjadi wakil tanpa ada pemberian wewenang dari yang punya hak yaitu wali atau mempelai lakilaki sekali tidak berhak melakukan akad nikah. Kalau secara sah, maka orang ini sama pun nekat juga, maka nikah itu tidak sah di mata Allah swt.

Satria Effendi M. Zein sebagai salah satu pakar yang membidangi masalah hukum keluarga Islam di Indonesia ini dalam bukunya "Analisis Yurisprudensi Mengenai Masalah Keluarga Islam Kontemporer Indonesia" memberikan analisis yurisprudensi yang cukup mendalam mengenai perkawinan melalui media telepon sebagaimana dikukuhkan Putusan Pengadilan Agama Jakarta Selatan No. 1751/P/1989. Dalam pendapatnya, Satria Effendi M. Zein menyatakan bahwa ada dua macam putusan yang dapat dipilih oleh majelis hakim mengenai masaíah ini, yaitu membolehkan sesuai dengan kecenderungan Madzhab Hanafi ataupun melarang sesuai dengan kecenderungan Madzhab Syafi;i. Di sini Satria Effendi M. Zein menyerahkan putusan yang diambil sesuai dengan dasar yang dipakai majelis hakim, dan memberikan penekanan bahwa keduanya boleh dipakai selama belum ada undang-undang yang secara jelas mengatur mengenai hal ini. Untuk itulah, disini penulis berusaha mengedepankan permasalahan ini, menjelaskan bagaimana metode ijtihad yang dipakai oleh Satria Effendi M. Zein dalam mengkritisi Putusan Pengadiian Agama Jakarta Selatan No. 1751/P/1989, dasar-dasar yang menjadi 
alasannya menentukan hukum yang sesuai, cara pandang ia melihat permasalahan ini dan pertimbangan-pertimbangan rasional dan ushuliyah yang ia pakai.

\section{Penutup}

Dari uraian yang penulis sampaikan di muka, dapat diambil kesimpulan bahwa nikah lewat telepon tidak boleh dan tidak sah, karena bertentangan dengan ketentuan hukum syariah dan peraturan perundang-undangan yang berlaku di Indonesia. Penetapan atau Putusan Pengadilan Agama Jakarta Selatan yang mengesahkan nikah lewat telepon No. 175/P/1989 tanggal 20 April 1990 merupakan preseden yang buruk bagi dunia Peradilan Agama di indonesia, karena melawan arus dan berlawanan dengan pendapat mayoritas dari dunia Islam. Penetapan peradilan agama tersebut hendaknya tidak dijadikan oleh para hakim pengadilan agama seluruh Indonesia sebagai yurisprudensi untuk membenarkan dan mengesahkan kasus yang sama.

\section{DAFTAR PUSTAKA}

Abdurrahman AL-Jaziri, AL-Figh 'ala al-Madzahib al-Arba'an. (Beirut:Dar al-Fikr, t.th)

Al-Haitsami, Tuhfatul Muhtaj, (Beirut: Dar al-Fikr, t.th)

An-Nawawi, Al-Majmu' Syarh al-Muhazzab, (Beirut: Dar al-Fikr, t.th)

Ibnu Qudamah, Al-Mughni, (t.tp: Matba' ah aiQahirah, 1970)

Satria Effendi M. Zein, Problematika Hukum Keluarga Islam Kontemporer: Analisis turisprudensi dengan Pendekauan Ushuliyyah, (Jakarta: Kencana Prenada Media, 2004)

Sayid Sabiq, Fiqh as-Sunnah, (Beirut: Dar al-Fikr, 1983)

Putusan Pengadilan Agama No. 1751/P/1989 Tentang Perkawinan Melalui Telepon 